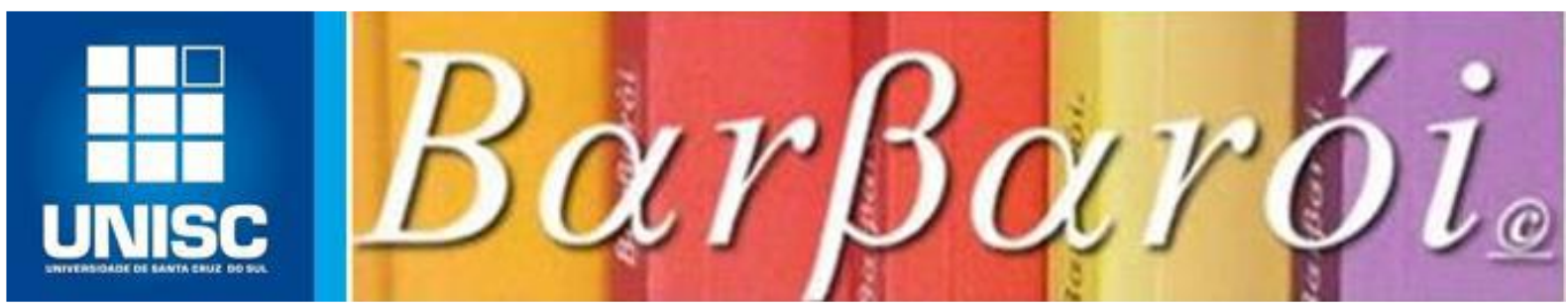

\title{
SER APRENDIZ: OS SENTIDOS DA JUVENTUDE NA POLÍTICA PÚBLICA DE APRENDIZAGEM PROFISSIONAL
}

\author{
DOI: http://dx.doi.org/10.17058/barbaroi.v0i58.7178 \\ $*$ \\ Thaís Ellen Gomes Provenzi \\ Universidade Federal do Paraná - UFPR - Brasil \\ Miriam Aparecida Graciano de Souza Pan \\ Universidade Federal do Paraná - UFPR - Brasil \\ $*$
}

\section{Resumo}

Este artigo analisa os sentidos atribuídos ao jovem configurado pela atual política pública brasileira de aprendizagem profissional e como operam as tecnologias de governo do indivíduo na produção da noção de risco social. Trata-se de um estudo documental com base na teoria de leitura de Mikhail Bakhtin, na qual se analisam os enunciados objetivando a sua desnaturalização. Um conjunto de normativas atinentes a essa política foi selecionado, lido e analisado enquanto textos e intertextos a produzir uma rede dialógica complexa que evidencia o posicionamento do Estado em relação ao significado de ser aprendiz, o qual envolve a noção de proteção social, portanto direcionado ao público alvo da política de assistência social. O sentido da identidade do jovem considerado de risco é o principal alvo da política, que regulamenta o trabalho antes dos 18 anos identificando-o como aprendiz. O estudo evidencia 0 caráter normativo e regulador desse processo, embora a esfera social seja complexa e requeira uma revisão constante. Diante da naturalização do conceito de juventude constatado, as políticas públicas voltadas para o jovem apresentam-se contraditórias e distantes das demandas específicas desta população. Este estudo aponta para a necessidade de problematizar os sentidos da proteção social para o jovem e para a sociedade, bem como os seus efeitos, especialmente na política de aprendizagem profissional, a qual não afeta somente o seu destinatário, mas a toda a sociedade, uma vez que atua na fabricação de um modelo identitário e gesta a existência dos indivíduos objetivando sua conformação.

Palavras-chave: juventude; aprendiz; política pública de aprendizagem profissional; risco social.

\section{INTRODUÇÃO}

Ser aprendiz no Brasil hoje é um forte convite aos jovens que buscam consolidar seu projeto de vida a conseguir seu primeiro emprego. A juventude protagoniza grande parte das 
atuais políticas públicas as quais tecem uma rede de intertextos no campo da educação, do trabalho e da assistência social, e por meio da política de aprendizagem profissional vigente produzem a condição de aprendiz. Contudo, compreender a concepção de juventude na sociedade contemporânea, especialmente como ela é significada na política pública de aprendizagem profissional, requer uma análise sobre a construção deste conceito de modo a situá-lo histórica, social e culturalmente.

Zanella et al (2013) aponta que a partir da década de 90 houve uma explosão na produção acadêmica, na atenção da mídia e da sociedade como um todo à situação dos jovens no país em função da mobilização social proveniente das discussões da década de 70 e 80, bem como do próprio Estatuto da Criança e do Adolescente e, especialmente, pelos processos de exclusão social constatados. Os autores concluem que predominam os artigos que analisam a concepção de juventude em estágios marcados pela entrada e saída do mundo do trabalho. Os textos na área da saúde e da assistência social atrelam a juventude ao conceito de risco, de periculosidade pessoal e social, evidenciando-se a lógica da tutela das instituições para com o jovem.

A política de aprendizagem profissional é uma proposta do Estado que envolve a esfera educacional, do trabalho e da assistência social, tendo ampla influência e impacto na vida de jovens provenientes de comunidades de baixa renda, tanto daqueles que conquistam uma vaga como aprendiz, como daqueles que não se inserem neste programa, seja de forma voluntária ou não. Relaciona-se, ainda, a uma proposta de erradicação do trabalho infantil. Ser aprendiz significa muito mais que conquistar o primeiro emprego, pois o programa de aprendizagem ocupa um lugar diferenciado no imaginário social. Assim, qual o sentido de ser aprendiz? Como a política de aprendizagem profissional delimitada pelo Estado brasileiro configura/produz a condição de ser aprendiz? Quais os fundamentos/pressupostos sobre a juventude nela contida?

Dimenstein (2010, p. 160) esclarece que as políticas públicas surgem em função de uma demanda de proteção social, a qual surge em virtude do descompasso entre as responsabilidades individuais e coletivas em função dos efeitos perversos do sistema econômico vigente.

Para Sposito (2008, p. 59), o "termo política pública compreende a dimensão éticopolítica dos fins da ação, e deve-se aliar, necessariamente, a um projeto de desenvolvimento econômico-social e implicar formas de relação do Estado com a sociedade". Machado e Pan $(2013$; 2014) acrescentam que as políticas públicas são ações que visam solucionar problemas políticos, extrapolando uma simples atuação burocrática do Estado e, portanto, não estão livres de um posicionamento ético-político, pois se situam nas relações de poder entre o Estado e a 
sociedade, reproduzindo como efeito os sentidos que elas anunciam.

Rua (1998) problematiza que no Brasil as políticas voltadas para o jovem apresentamse fragmentadas, com uma implementação que destoa de seu desenho, e distantes das demandas específicas desta população. Sposito (2008) complementa denunciando que o papel dos jovens não é bem definido no modelo de desenvolvimento atual e estes não são ouvidos na formulação e avaliação destas políticas que lhes dizem respeito.

Diante dos inúmeros estudos publicados sobre a juventude que buscam compreender quem é este jovem e responder às demandas emergentes na sociedade contemporânea (ZANELLA ET AL, 2013), cabe analisar os discursos circulantes e os efeitos que estes produzem sobre os modos de subjetivação, especialmente na política pública de aprendizagem profissional, como tecnologias de governo do indivíduo, pois conforme os estudos de Michel Foucault (1926-1984) defendiam "é preciso conhecer o governo a que estamos submetidos para que seja possível alguma autonomia” (SCISLESKI; GUARESCHI, 2010, p. 167).

Conforme explica Foucault (2010), o Estado é responsável pelas políticas públicas e estas são produzidas em uma sociedade que é constituída de relações de poder; as relações de poder não se referem às estruturas específicas ou a uma classe dominante, mas sim às relações humanas, sejam elas quais forem. O poder sempre estará presente nestas relações e de forma dinâmica, podendo alterar-se.

As relações de poder foram governabilizadas de modo a serem tuteladas pelas instituições do Estado, "Estado que utilizará um conjunto de estratégias para fazer funcionar ou para manter uma relação de poder que beneficie, no caso da cultura ocidental, o Capital, o Mercado" (ALVES, 2011, p. 50).

Dimenstein (2010) avalia que as políticas públicas gestam formas de vida e fabricam modelos identitários fixos. Elas se referem a uma economia do poder que objetiva a modelagem de cada indivíduo e a gestão de sua existência. É um processo que extrapola o interior das instituições e atinge todo o campo social regulando todas as vidas, não somente aquelas que se beneficiam dos serviços ou benefícios ofertados. Como elas abarcam uma visão de homem e de mundo, precisam ser constantemente debatidas e revistas a fim de que analisem a complexidade da esfera social e sejam menos normativas.

Considerando que a concepção de juventude é uma construção social, histórica e cultural (SALLES, 2005; ARIÈS, 1978), que as pesquisas recentes na área da assistência social têm atrelado a juventude ao conceito de risco, de periculosidade pessoal e social, bem como, que a visão de homem e de mundo contida nas políticas públicas constituem parâmetros que atuam 
na modelagem do indivíduo e de toda a sociedade, este artigo objetiva analisar os sentidos atribuídos ao jovem configurado pela política pública de aprendizagem profissional.

\section{MÉTODO}

O percurso desta pesquisa partiu de uma investigação dos documentos legais relativos à aprendizagem profissional e à assistência social no Brasil, realizando um estudo documental conforme definido por Flick (2009) e Spink et al (2014) e com base na teoria de leitura de Mikhail Bakhtin, conforme procedimento adotado por Machado e Pan (2012) e replicado por Souza (2014), no qual se analisam os enunciados (BAKHTIN, 1988, p.82) objetivando a sua desnaturalização.

Esta trajetória iniciou a partir da seleção de uma amostra representativa dos documentos legais atinentes à política de aprendizagem profissional e à política nacional de assistência social a fim de compreender o discurso oficial sobre a concepção de trabalho para jovens de 14 a 16 anos e o discurso oficial da proteção social aos jovens. As normativas foram consultadas integralmente ou em partes, com o objetivo de selecionar os trechos que correspondiam exatamente ao tema proposto nesta pesquisa. Deste modo, obteve-se o seguinte recorte, nesta ordem de leitura, a qual fora assim definida em razão do nível crescente de detalhamento da temática investigada:

- Lei $\mathrm{n}^{\circ} 10.097 / 2000$ (A Lei da Aprendizagem);

- Manual da Aprendizagem (Elaborado pelo Ministério do Trabalho e Emprego);

- Decreto $n^{\circ}$ 5.598/2005 (Regulamenta a contratação de aprendizes);

- Constituição da República Federativa do Brasil, art. $7^{\circ}$, inciso XXXIII e art. 227, § $3^{\circ}$, inciso I;

- Projeto de Lei $\mathrm{n}^{\mathrm{o}}$ 2.845/2000. (Altera dispositivos da Consolidação das Leis do Trabalho);

- Lei nº 8.069/1990 (Estatuto da Criança e do Adolescente);

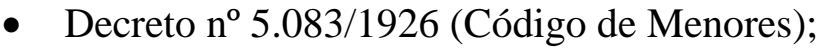

- Política Nacional de Assistência Social;

- Resolução no 33/2011 (Define a promoção da integração ao mercado de trabalho no campo da assistência social);

- Lei $n^{\circ} 12.435 / 2011$ (Altera a Lei no 8.742, de 7 de dezembro de 1993, que dispõe sobre a organização da Assistência Social);

- Lei $n^{\circ}$ 12.868/2013 (Introduziu mudanças com relação à Lei da Filantropia);

Barbarói, Santa Cruz do Sul, n. 58, p.<65-94>,jan./jun. 2021 
- Orientações Técnicas - Programa Nacional de Promoção de Acesso ao Mundo do Trabalho (ACESSUAS Trabalho).

Todos os documentos acima listados foram acessados e copiados dos sites oficiais.

Os textos foram lidos e analisados enquanto textos e intertextos a produzir uma rede dialógica complexa que evidencia o posicionamento do Estado em relação ao que significa ser aprendiz na atual política de aprendizagem profissional.

Para tornar possível a analise do sentido do jovem enquanto aprendiz conforme significado na política de aprendizagem profissional, importa primeiramente compreender como esta e a política de assistência social, a qual se dedica ao mesmo público-alvo, respondem à Constituição da República Federativa do Brasil, instituindo práticas que a viabilizem. Em seguida, importa situar historicamente a educação profissional e a aprendizagem no país e analisar como o jovem é retratado na sociedade contemporânea em diálogo com a condição do aprendiz para abordar a questão da identidade e do governo na política de aprendizagem profissional.

\section{PROTEÇÃO SOCIAL E TRABALHO COMO DIREITOS SOCIAIS: IMPLICAÇÕES PARA O SURGIMENTO DAS ATUAIS POLÍTICAS DE APRENDIZAGEM E PARA A CONFIGURAÇÃO DO APRENDIZ}

A Constituição da República Federativa do Brasil - CRFB (BRASIL, 1988), em seu art. $6^{\text {o }}$, elegeu a educação, o trabalho e a proteção à infância como direitos sociais (ou seja, direitos fundamentais de segunda dimensão).

Defende-se na Carta Magna que a educação, como direito social, exige do Estado uma atuação positiva na busca da sua plena efetivação. Há o dever de se criar condições normativas que viabilizem o exercício desse direito, como por exemplo, a Lei de Diretrizes e Bases da Educação Nacional -LDB, e condições reais, como recursos humanos, estrutura etc. - em outras palavras, garantias institucionais.

No Brasil vige o princípio de que a educação ofertada pelos estabelecimentos oficiais será gratuita (é vedada qualquer espécie de cobrança, tais como taxa de matrícula, de expedição de diploma, dentre outras). Entretanto, a própria Constituição (BRASIL, 1988) somente considera como dever do Estado o oferecimento da educação fundamental e obrigatória, não prevendo esse dever com relação ao ensino médio (exigindo apenas sua progressiva universalização) e superior (que tem o seu acesso mediante a capacidade e os méritos próprios de cada um, como se confere na Carta Magna, em seu art. 208, inciso V). 
O valor social do trabalho foi eleito como um dos fundamentos da República Federativa do Brasil (BRASIL, 1988, art. $1^{\circ}$, inciso IV), sendo considerado, também, um dos pilares da ordem econômica (BRASIL, 1988, art. 170, caput). Caracteriza-se o direito a um trabalho digno como um direito fundamental de segunda dimensão, exigindo para a sua implementação uma atuação positiva por parte do Estado (caráter prestacional).

O trabalho encontra sua proteção constitucional no extenso rol de direitos e garantias previstos nos arts. $7^{\circ}$ a 11 da CRFB (BRASIL, 1988), restando claramente defendida a proteção ao trabalho infantil no inciso XXXIII do art. $7^{\circ}$ : "proibição de trabalho noturno, perigoso ou insalubre a menores de dezoito e de qualquer trabalho a menores de dezesseis anos, salvo na condição de aprendiz, a partir de quatorze anos.” (BRASIL, 1988)

No tocante à proteção da infância, resta previsto no art. 227 da CRFB que "é dever da família, da sociedade e do Estado assegurar [...] ao adolescente e ao jovem, com absoluta prioridade, o direito [...] à profissionalização, à dignidade, [...] além de colocá-lo a salvo de toda forma de negligência, discriminação, exploração, violência [...] e opressão".

Logo, o Estado se impõe o dever de proteção e regulação do trabalho precoce, ou seja, a erradicação do trabalho infantil, de forma a assegurar à criança e ao adolescente um desenvolvimento pleno, defendendo que seja evitada e erradicada toda forma de trabalho infantil.

A política pública de aprendizagem, por sua vez, se apresenta como uma ação do Estado no sentido de proteção à infância, regulando o trabalho do jovem de 14 a 24 anos e envolve a educação e o trabalho, buscando atender o jovem definido na Política Nacional de Assistência Social- PNAS (BRASIL, 2004), isto é, em situação de risco e vulnerabilidade social por motivo de pobreza, identidades estigmatizadas, alternativas diferenciadas de sobrevivência que possam representar risco pessoal e social, entre outros, inserindo-o no mercado formal de trabalho.

Portanto, o discurso das garantias à proteção da infância, dos direitos sociais, da proteção ao trabalho infantil, da valorização do trabalho como um pilar da ordem econômica e da obrigatoriedade da educação fundamental versus o acesso ao ensino superior conforme a capacidade e os méritos próprios de cada um demonstram o posicionamento do Estado frente às questões sociais, o enquadramento da família e do jovem nas expectativas do Estado, a relação que se espera do jovem com a educação e com o mundo do trabalho, bem como a descrição do perfil deste jovem em comparação ao padrão estabelecido para a sociedade em geral.

Diante disso, surge a seguinte questão: a politica de aprendizagem profissional é uma Barbarói, Santa Cruz do Sul, n. 58, p.<65-94>,jan./jun. 2021 
proposta recente, isto é, emerge a partir da Constituição Federal?

\subsection{HiSTÓRICO DA EDUCAÇÃO PROFISSIONAL: PARA AS CLASSES POPULARES DESDE O BRASIL COLÔNIA}

A história do surgimento da educação e da aprendizagem profissional no Brasil, a qual remonta ao período Colonial, Imperial e Republicano, demonstra que sua trajetória sempre esteve dedicada às classes populares com o objetivo de torna-las produtivas, diferindo da educação voltada para as classes economicamente favorecidas, a qual apresenta um caráter seleto e academicista (SALES; OLIVEIRA, 2010).

Como descreve Sales e Oliveira (2010), o ensino de ofícios no Brasil Colônia era dedicado aos jovens que não tivessem outra escolha, como por exemplo, aqueles desprovidos de condições sociais e econômicas. O objetivo principal era prepará-los para o artesanato, a manufatura e a indústria, atividades desprestigiadas devido ao preconceito contra o trabalho físico e manual. Existiam algumas normas que já se preocupavam em regular os direitos e deveres desta aprendizagem profissional incipiente, a qual se dava fora do ambiente escolar tradicional - pois esta fora criada originalmente com o intuito de preparação intelectual da classe dominante para o exercício do poder - e tinha como objetivo principal se amoldar às demandas do antigo regime português e à organização social da época.

No tempo do Império, surgiram diversas iniciativas por parte do Estado e das associações civis para a educação profissional, adotando como base o modelo militar de hierarquia e disciplina. O Estado destinava verbas públicas para o ensino privado a fim de financiar o ensino profissional de cunho beneficente. A elite do Brasil imperial percebeu o ensino profissional como um meio de manter a ordem e mobilizar a força de trabalho para a indústria. Observa-se, portanto, que neste período o ensino profissional continuou a ser desvalorizado, porém, envolto em um caráter assistencialista e moralizador.

Durante a primeira República, houve a criação do Decreto $n^{\circ} 439 / 1890$, que regulamentou a assistência aos jovens desvalidos e o Decreto $\mathrm{n}^{\circ}$ 1.313/1891 estabeleceu os princípios para regularizar o trabalho dos menores nas fábricas do Rio de Janeiro, as quais estavam se expandindo nesta capital federal. Neste último já se delimitava a idade e o horário permitidos para o trabalho, se caracterizava o trabalho como aprendizado e se iniciava a noção de trabalho protegido. Um marco importante foi a criação das Escolas de Aprendizes Artífices, em 1909, por Nilo Peçanha, iniciativa esta apontada como fundamental para o surgimento dos futuros Centros Federais de Educação Tecnológica (CEFETs), os quais foram criados por meio 
do Decreto $n^{\circ} 7.566 / 1909$. Nesta ocasião o discurso oficial explicitado pelas políticas públicas era de que os hábitos de trabalho poderiam afastar a ociosidade, o vício e prevenir o crime. Observa-se ainda que as pessoas com deficiência também sofriam discriminação neste âmbito. É importante destacar que neste período, o pensamento que permeava a República era calcado no liberalismo e no positivismo, de modo a incentivar a disciplinarização preventiva dos desvalidos, qualificação para o trabalho e combate aos desvios do padrão social vigente (SALES; OLIVEIRA, 2010).

Em 1942 estruturou-se o ensino profissional, por meio de leis orgânicas, porém, manteve-se o caráter dualista do ensino (formação intelectual versus formação de trabalhadores). Esta dualidade veio a ser confrontada pelo posicionamento de educadores críticos à época e especialmente pela primeira Lei de Diretrizes e Bases da Educação Nacional, Lei $n^{\circ} 4.024 / 1961$, que propôs a equivalência geral entre os ciclos do ensino médio.

A Lei da Aprendizagem surge em 1943, devido à promulgação da CLT com a ditadura varguista, apresentando como obrigatória às indústrias a contratação de aprendizes, entre quatorze e dezoito anos, e suas matrículas em cursos de aprendizagem, os quais eram oferecidos pelo SENAI e SENAC. A obrigatoriedade estendeu-se também a estabelecimentos comerciais a partir do Decreto-Lei no 8.622/1946.

Com o desenvolvimento social e econômico brasileiro, o cenário legal da aprendizagem foi se adaptando às novas demandas - embora algumas características permaneçam, como por exemplo: a prática de ensino e de trabalho conjugadas e o público-alvo composto por jovens de camadas sociais em vulnerabilidade -, culminando em normativas que são consideradas atualmente como marcos legais para a aprendizagem profissional, as quais são explicitadas a seguir.

Cabe, então, analisar qual é a legislação vigente da aprendizagem profissional no Brasil.

\subsection{SER APRENDIZ NO BRASIL DE HOJE}

No Brasil, o sistema legal vigente relativo à aprendizagem contempla principalmente a Lei ${ }^{\circ} 10.097 / 2000$, o Decreto $n^{\circ} 5.598 / 2005$, o qual regulamentou a primeira, e o Estatuto da Criança e do Adolescente - ECA.

A Lei $n^{\circ}$ 10.097/2000 altera dispositivos da Consolidação das Leis do Trabalho - CLT que em seu art. 403 passa a proibir "qualquer trabalho a menores de dezesseis anos de idade, salvo na condição de aprendiz, a partir dos quatorze anos". Portanto, o menor, para efeitos desta normativa, em seu parágrafo único do art. 403, é o trabalhador de quatorze até dezoito anos, o 
qual deve desempenhar sua prática de aprendizagem em local adequado, isto é, que não o exponha a prejuízos relativos "à sua formação, ao seu desenvolvimento físico, psíquico, moral e social e em horários e locais que não permitam a frequência à escola".

Tal contrato de aprendizagem é definido como contrato de trabalho especial (BRASIL, 2000b), o qual é condicionado a ser escrito, pressupõe anotação na Carteira de Trabalho e Previdência Social, deve ter prazo determinado de no máximo dois anos e responsabilizar o empregador pela formação técnico-profissional metódica do menor, já devidamente inscrito em programa de aprendizagem sob a orientação de entidade qualificada, e asseverar que este, na condição de aprendiz, esteja matriculado e frequentando a escola, caso não haja concluído o ensino fundamental, bem como, execute com o devido comprometimento as tarefas inerentes a sua formação, a qual deve ser compatível com o seu "desenvolvimento físico, moral e psicológico", conforme preconiza a citada legislação (BRASIL, 2000b).

Esta formação técnico-profissional refere-se a um conjunto de atividades teóricas e práticas, organizadas sistematicamente de modo que o nível de complexidade seja progressivo e, em consonância com o Estatuo da Criança e do Adolescente - ECA (BRASIL, 1990), em seu Art. $68, \S 1^{\circ}$, priorize o aspecto pedagógico em detrimento do produtivo no ambiente de trabalho. O Decreto ${ }^{\circ} 5.598 / 2005$ (BRASIL, 2005), em seu Art. $7^{\circ}$, inciso III explicita que esta formação deve oportunizar "capacitação profissional adequada ao mercado de trabalho". Ainda, ao término do curso de aprendizagem, mediante avaliação de aproveitamento, será concedido aos aprendizes certificado de qualificação profissional. Em síntese, o trabalho é assegurado ao adolescente como um direito que envolve profissionalização e proteção.

$\mathrm{O}$ contrato de aprendizagem pode extinguir-se no seu termo ou quando o aprendiz completar a idade limite de dezoito anos ou antecipadamente, segundo o art. 433, incisos I a IV da Lei n" 10.097/2000 (BRASIL, 2000b), em caso de "desempenho insuficiente ou inadaptação do aprendiz; falta disciplinar grave; ausência injustificada à escola que implique perda do ano letivo; ou a pedido do aprendiz".

Em linhas gerais, estabelecimentos de qualquer natureza são obrigados a contratar aprendizes em número equivalente a cinco por cento, no mínimo, e quinze por cento, no máximo, dos trabalhadores existentes em seu quadro de pessoal, cujas funções demandem formação profissional. Entretanto, não é dever da Administração Pública, com exceção das sociedades de economia mista e empresas públicas (BRASIL, 2011c), a contratação de aprendizes, ou seja, nesse âmbito específico a execução de um programa de aprendizagem é discricionária. 
Em síntese, este é o contorno dado pela legislação vigente ao tema trabalho na adolescência, o que denota os sentidos da infância e adolescência próprios da sociedade atual, e a demanda por proteção social enquanto direito social, o qual defende a concepção de trabalho protegido, ou seja, reclama a erradicação do trabalho exploratório. Esta representação do que é lícito e do que é, por outro lado, trabalho infantil, como uma ação exploratória sofrida pelas crianças e adolescentes, que até mesmo encontra políticas públicas que buscam a sua erradicação, é bastante recente, o que pode ser comprovado por uma simples consulta às datas dos documentos legais que tratam deste assunto por este viés.

Outro modo bastante peculiar de observação e fundamentação do caráter moderno desta discussão é a mudança cultural que ainda se expressa de forma gradativa nas famílias e na sociedade em geral, pois conforme explicita Cruz Neto e Moreira (1998), ainda está presente no senso comum a ideia de que é melhor trabalhar do que ficar na ociosidade e muito do que se prevê nas legislações ainda aguarda a implementação do poder público. Kassouf (2007) demonstra que crianças de famílias que trabalharam precocemente tem maior probabilidade de serem submetidas a trabalho infantil, este é outro aspecto que ilustra a cultura ainda difundida sobre o trabalho, que o define como ferramenta de enobrecimento e dignificação do homem.

No entanto, as pesquisas recentes, conforme mencionado por Kassouf (2007) e Cruz Neto e Moreira (1998), apontam para o caminho inverso: da valorização do brincar e do estudar, as quais embasam os argumentos legais. E as gerações atuais também se deparam com o dever sociocultural e até mesmo moral de assumir uma posição favorável à erradicação do trabalho infantil. Nesse sentido, Salles (2005) aponta a influência da cultura para a compreensão da relação entre crianças e adultos, bem como o entendimento sobre as trajetórias de desenvolvimento infantil e a organização dos ambientes familiar e escolar considerando que a subjetividade sofre a influência dos referenciais linguísticos, dos signos, da "organização social e cultural na qual os indivíduos estão inseridos" (2005, p. 34). Deste modo, a política pública em tela compõe um referencial linguístico que influencia os modos de subjetivação com relação à concepção de trabalho que se espera na sociedade atual para esta faixa etária.

No entanto, embora se use o termo erradicação, constata-se que a lei da aprendizagem teve como objetivo regular o trabalho e não proibi-lo, portanto, há um redesenho das condições de trabalho que inicialmente eram expressas em contextos familiares, nos quais era comum uma composição numerosa de filhos para o fortalecimento da mão-de-obra para as atividades laborativas, que se concentravam geralmente na agricultura familiar. Este redesenho, portanto, aponta para as demandas de uma sociedade industrializada. Salles (2005) indica que na 
atualidade há uma identidade de criança e adolescente alicerçada na cultura da informação, do consumo e no imediatismo. E esta caracterização da infância e da adolescência é muito própria da sociedade industrial e se liga às leis trabalhistas e ao sistema educacional. Com a separação entre seres adultos e seres em idade de escolarização, inicialmente nas famílias burguesas, conforme explica Ariès (1978), houve o progressivo afastamento da criança deste mundo do trabalho, o qual paulatinamente se estendeu a toda a sociedade. Ariès (1978) explicita também que, ao longo deste processo, é dado um caráter inquestionável e universalizante aos ditos fenômenos da adolescência como sendo próprios de uma fase. Associou-se à infância, desta forma, um status de dependência, não responsabilidade jurídica, política e emocional, conforme sintetiza Salles (2005).

Surge, então, uma concepção de disciplinarização da infância e adolescência para a socialização e posterior inserção adaptada no mundo do trabalho - e este papel é designado à escola. Desde os anos 20, surgem também, políticas públicas e estudos médicos, psicológicos e pedagógicos com o objetivo de normatizar e explicar os comportamentos observados nestas diferentes fases da vida (SALLES, 2005). Diante da nova configuração de família, muitas das funções que antes eram desempenhadas por esta, como a função de socialização, por exemplo, passam a ser delegadas às instituições, como à escola e à assistência social, ou seja, o Estado passa a tutelar estas relações de poder.

Diante da recente noção de trabalho protegido, que milita pela erradicação do trabalho exploratório, porém, ainda não conseguiu superar o sentido moral do trabalho como sendo aquele que dignifica o homem e, ainda, se expressa na política de aprendizagem profissional como regulação do trabalho em resposta aos preceitos da sociedade capitalista, surge o sentido de disciplinarização da adolescência a partir da caracterização dos seus fenômenos como sendo próprios de uma fase, que requer proteção por não manifestar responsabilidade jurídica, política e emocional, para a posterior inserção adaptada no mundo do trabalho.

Ser aprendiz no Brasil de hoje, desse modo, envolve a noção de proteção social, a qual instiga uma análise pormenorizada sobre a trajetória da assistência social como direito no Brasil. Importa destacar que embora a legislação da aprendizagem não evidencie o público-alvo da assistência social como sendo o seu destinatário, há uma relação histórica existente entre a educação profissional e a aprendizagem profissional no Brasil e os jovens das classes populares. 


\section{ASSISTÊNCIA SOCIAL COMO DIREITO À PROTEÇÃO SOCIAL: APRENDIZ EM FOCO}

Silva e Corgozinho (2011) apresentam o Sistema Único de Assistência Social (SUAS) como uma política social recente, datada de 2005.

De acordo com Silva e Corgozinho (2011), a história do SUAS remonta à década de 30, com seus movimentos sociais populares, os quais requeriam a intervenção do Estado no reconhecimento e ampliação dos direitos sociais. A partir do final dos anos 70, tais lutas surtiram efeito e suas vitórias no campo da democratização culminaram na nossa carta magna, a Constituição Federal de 1988, a qual marcou o reconhecimento da assistência social como direito e determinou a distribuição das suas competências entre União, Estados e Municípios, junto ao Distrito Federal, estimulando a participação coletiva.

A assistência social é então colocada ao lado da saúde e da previdência, compondo o tripé da seguridade social e em 1993 é promulgada a Lei Orgânica da Assistência Social, "que a torna, no Brasil, um direito de todos os cidadãos e dever do Estado" (SILVA; CORGOZINHO, 2011, p. 13), mudando seu status legal e político.

Estes autores detalham as particularidades do SUAS em um breve resumo caracterizando-o "como um sistema público não contributivo, descentralizado e participativo que tem por função a gestão do conteúdo específico da assistência social no campo da proteção" (SILVA; CORGOZINHO, 2011, p. 13).

Para que estes objetivos se cumpram, Silva e Corgozinho (2011) enfatizam que o foco de atuação do SUAS está em reduzir e prevenir situações de vulnerabilidades e riscos sociais, surgidos em função dos ciclos de vida, faixas etárias identificadas como prioritárias para o atendimento (crianças, jovens e idosos) e da fragilização de vínculos. A fim de garantir prevenção e atendimento das situações já instaladas, o SUAS divide-se em dois níveis de complexidade: a proteção social básica, com os Centros de Referência da Assistência Social CRAS e a proteção social especial, subdividida em média e alta complexidade, com os Centros de Referência Especializado de Assistência Social - CREAS.

As citadas autoras defendem que a assistência social, antes de se tornar um direito social, era um campo de conflitos obscuros, pois a questão social era discutida muito mais por um dever moral do que por um dever político ligado aos direitos de cidadania. Ximenes, Paula e Barros (2009, p. 689) citam ainda que as ações assistenciais eram, até então, "marcadas por práticas assistencialistas e filantrópicas".

O propósito maior do SUAS, conforme síntese de Silva e Corgozinho (2011, p.14) é 
“efetivar uma rede de proteção social estável e sustentável, a partir de um novo modelo gestão (...), garantindo autonomias legais em regime de mútua colaboração institucional num sistema hierarquicamente regulado em termos de vínculos e responsabilidades”.

Ximenes, Paula e Barros (2009), por outro lado, tecem uma crítica ao processo de efetivação da política de assistência social tal como prevista na Constituição de 1988, pois segundo os autores esse processo aconteceu, e continua acontecendo, de forma contraditória, em um contexto de gestão que ao mesmo tempo em que faz concessões à ideologia neoliberal, incumbe o Estado de implementar e de desenvolver políticas públicas de proteção social. Ainda, segundo estes autores, mesmo após a promulgação da Constituição de 1988, muitos de seus preceitos não foram concretizados e continuam sendo um desafio em função das "fortes marcas clientelistas e assistencialistas que caracterizam a história das práticas assistenciais no Brasil" (XIMENES; PAULA; BARROS, 2009, p. 689). O crescimento do terceiro setor na década de 90, ao lado do serviço voluntário, é apontado por estes autores como um dos exemplos de perpetuação destas práticas, eximindo o Estado do seu papel de agente da proteção social do país.

De acordo com a PNAS (BRASIL, 2004), é função do CRAS realizar o mapeamento e a organização da rede socioassistencial de proteção básica, atendendo as famílias referenciadas e encaminhando a população para as demais políticas públicas e sociais, sendo este último um ponto de interseção onde o mundo do trabalho se insere.

Uma das responsabilidades do CRAS é ofertar programas e projetos de capacitação e promoção da inserção produtiva e de geração de trabalho e renda (SILVA; CORGOZINHO, 2011). No entanto, Ximenes, Paula e Barros (2009) ponderam que não compete somente à assistência social responsabilizar-se pelo atendimento das demandas sociais. E estes autores lembram que ainda persistem as dificuldades ligadas aos "interesses democráticos e eleitoreiros" as quais podem impactar na ação das equipes restringindo, por exemplo, a atuação dos psicólogos "a práticas normatizantes, a serviço da agenda de grupos políticos à frente das engrenagens governamentais" (XIMENES; PAULA; BARROS, 2009, p. 696).

E, ainda, além de enfrentar desafios, como o de superar as marcas históricas do assistencialismo e os interesses eleitoreiros que transformam políticas públicas em políticas partidárias, configura o exercício da proteção social atendendo aos princípios do neoliberalismo. O crescimento do $3^{\circ}$ setor - que tem participação prevista e autorizada como entidade qualificada para a formação teórico-metódica na política de aprendizagem profissional -, é um exemplo de perpetuação destas práticas, eximindo o Estado do seu papel de agente da 
proteção social.

Considerando a relação histórica existente entre a educação profissional e a aprendizagem no Brasil e os jovens das classes populares, importa pensar como a discussão sobre o mundo do trabalho se insere na assistência social na atualidade.

\subsection{DIÁLOGOS ENTRE A ASSISTÊNCIA SOCIAL E O MUNDO DO TRABALHO}

Como o mundo do trabalho é contemplado nas políticas públicas específicas de trabalho e emprego, é relevante compreender como a assistência social articula as ações correspondentes a este campo sem perder sua especificidade, já que, a depender da leitura que se faça, a política de aprendizagem profissional poderia ser enquadrada somente como uma política de trabalho e emprego.

O Estatuto da Criança e do Adolescente - ECA (BRASIL, 1990) inaugura uma mudança de paradigma no entendimento e na construção de propostas de intervenção direcionadas ao universo infanto-juvenil e define ordenamentos legais que pressupõem a construção de Políticas Sociais para o alcance de metas e objetivos, considerando crianças e adolescentes como sujeitos de direito. A assistência social, diante desta análise do Estatuto, compreende que o programa de aprendizagem profissional atua nesta interseção entre ambas as políticas, de assistência social e de trabalho e emprego.

Com relação ao âmbito do trabalho, a Lei nº. 12.435/2011, a qual alterou a Lei Orgânica da Assistência Social - LOAS - nº 8.742/1993, em seu artigo $2^{\circ}$, inciso I, alínea c, estabelece como um de seus objetivos a "Integração ao Mercado de Trabalho" (BRASIL, 2011a, p.1).

A Resolução nº. 33/2011 - CNAS, que define a Promoção da Integração ao Mercado de Trabalho no campo da assistência social e estabelece seus requisitos, considera que "os indivíduos e famílias devem ser atendidos no conjunto de suas vulnerabilidades, identificadas a partir do processo de integração ao mundo do trabalho" (BRASIL, 2011b, p.115).

O Programa Nacional de Promoção do Acesso ao Mundo do Trabalho - ACESSUAS TRABALHO (BRASIL, 2013b) introduz a noção de mundo do trabalho em substituição a mercado de trabalho por se tratar de um conceito mais amplo e adequado aos desafios da política de assistência social. Ademais, apresenta a mobilização e o encaminhamento de adolescentes a partir de 16 anos de idade para cursos de capacitação profissional como uma das ações indicadas para o atendimento do público prioritário da política, por reconhecer a necessidade de buscar o fortalecimento dos vínculos familiares e sociais por meio de ações socioeducativas que promovam o acesso ao mundo do trabalho. Reconhece, ainda, que é papel da assistência social 
“identificar e acolher as demandas, mobilizar e garantir direitos e ser vocalizadora da população em vulnerabilidade", de modo que se resgate a autoestima, a autonomia e a resiliência (BRASIL, 2013b, p. 7) na integração ao mundo do trabalho.

Este trecho, em especial, merece destaque, pois a política pública em tela se propõe vocalizadora da população, aquela que reconhece o que o público necessita e pressupõe o resgate da autoestima, da autonomia e da resiliência, considerando estas características como ausentes. A aprendizagem destas competências se mostra aqui diretamente relacionada ao papel da assistência social.

A Lei $n^{\circ} 12.101 / 2009$, alterada pela Lei $n^{\circ} 12.868 / 2013$ (BRASIL, 2013a), no inciso II do art. 18 dispõe sobre os programas de aprendizagem de adolescentes, de jovens ou de pessoas com deficiência a fim de que sejam prestados com a finalidade de promover a integração ao mercado de trabalho, observadas as ações protetivas previstas na Lei no 8.069, de 13 de julho de 1990. Trata-se, portanto, de um marco para o reconhecimento da operacionalização dos programas de aprendizagem no âmbito da assistência social.

Sendo assim, a política de assistência social é convocada a pensar nas ações de articulação com o mundo do trabalho, pois cabe a ela convocar vontades, sensibilizar a população em situação de risco e vulnerabilidade social para suas potencialidades e para o universo de oportunidades construindo uma ponte entre os usuários da assistência social e a política pública de trabalho e emprego. Esta prática é, portanto, compreendida como intersetorial, especialmente no município de Curitiba (2013).

Tendo compreendido os diálogos possíveis entre a assistência social e o mundo do trabalho, especificamente que a política de aprendizagem profissional tem um papel importante para o alcance dos objetivos da assistência social, é preciso analisar o contorno dado pela política nacional de assistência social ao jovem, haja vista que esta descreve as características da população que será atendida na política de aprendizagem.

\subsection{O JOVEM RETRATADO PELA POLÍTICA NACIONAL DE ASSISTÊNCIA SOCIAL}

A Política Nacional de Assistência Social - PNAS objetiva atender a população em situação de risco e vulnerabilidade social, a qual é descrita como: 
informal; estratégias e alternativas diferenciadas de sobrevivência que podem representar risco pessoal e social [grifos meus] (BRASIL, 2004, p. 33).

Quando a PNAS usa o termo ciclos de vida, está se referindo a crianças, adolescentes, jovens, adultos e idosos em função de se tratar de faixas etárias que demandam atenção especial no que se refere à proteção social. Com isso, assume-se uma concepção de desenvolvimento humano e de aprendizagem.

A PNAS afirma ainda que a proteção social proposta por ela demanda um olhar sobre as pessoas, as suas circunstâncias e dentre elas seu núcleo de apoio primeiro, isto é, a família. A proteção social exige a capacidade de maior aproximação possível do cotidiano da vida das pessoas, pois é nele que riscos, vulnerabilidades se constituem [grifos meus] (BRASIL, 2004, p. 15).

Nesta esteira, além da PNAS, é fundamental observar a justificativa do projeto de Lei $n^{\circ} 2.845 / 2000$ (BRASIL, 2000a), cuja aprovação resultou na Lei ${ }^{\circ} 10.097 / 2000$, conhecida como a Lei da Aprendizagem, a qual afirma que "a profissionalização é um direito primordial do adolescente e é a alternativa possível a esses jovens" (BRASIL, 2000a, p. 92). E ainda, argumenta que a citada Lei

se traduzirá em benefício para cerca de 7 milhões de jovens entre 14 e 16 anos, que necessitam de renda, de educação e de formação para ingresso no mercado de trabalho, cada vez mais exigente quanto à qualificação profissional e pessoal [grifos meus] (BRASIL, 2000a, p. 92).

Sendo assim, as normativas jurídicas defendem a elaboração de políticas públicas a fim de atender as demandas sociais identificadas e manter ou estabelecer uma determinada ordem social.

No entanto as políticas sociais são "tensionadas pela contradição entre cumprir com sua responsabilidade e responder a uma política econômica voltada para a redução dos gastos públicos" (SCISLESKI; GUARESCHI, 2010, p. 160). Sendo assim, a política pública pode, em princípio, objetivar a garantia dos direitos sociais, mas em última instância, reforçar as desigualdades socioculturais não garantindo estes direitos sociais.

Scisleski e Guareschi (2010, p. 179) discutem que os regimes democráticos "não $\operatorname{afasta}(\mathrm{m})$ a exceção como governo, mas justamente possibilita(m) a criação de técnicas sutis que, em nome da democracia, protegem a sociedade dos sujeitos considerados uma ameaça permanente".

Historicamente, conforme demonstrado por Hadler (2010), a assistência à juventude no Brasil tem a marca do olhar sobre a deficiência e os problemas, bem como da busca pela normalização, da regulamentação e, nesse sentido, as políticas públicas incorporam o sentido do risco, do diferente que demanda normalização, por meio do uso de estratégias de 
intervenção, prevenção e controle. Assim, “o jovem acaba sendo considerado tanto como perigo como fardo social" (HADLER, 2010, p. 308), discurso este que embasou a implementação de órgãos e normativas específicas a partir dos anos 20. O termo menor, proveniente do Código de Menores, conforme lembra Hadler (2010) ajudou a dar forma à noção de periculosidade.

Diante do exposto, a proteção social e o trabalho, descritos na Constituição Federal do Brasil como direitos sociais, podem ocultar uma realidade perpassada pela marca do assistencialismo e da ideologia neoliberal, apresentando uma leitura sobre as demandas sociais que foca na ordem social e acaba por reforçar as desigualdades socioculturais. A proteção social passa a ser a proteção da sociedade em detrimento daqueles que são diferentes e que, portanto, demandam normalização. Os jovens das camadas populares encontram, assim, na sociedade contemporânea uma nova forma de significação.

Ser aprendiz, portanto, é uma forma dócil de nominar o outro, traçando sua possível trajetória ou projeto de vida com a promessa de inclusão no mercado de trabalho, por meio da oferta de educação. E, ao mesmo tempo, é uma forma de delimitar a conformação de sua identidade, pois ser aprendiz não é para todos, é um direito que a proteção social delimita.

\subsection{SENTIDOS DA JUVENTUDE NA CONTEMPORANEIDADE}

Quando se faz menção à infância e à adolescência como uma das fases do desenvolvimento, tais concepções indicam construções contemporâneas, as quais estão situadas em um determinado contexto histórico, social e cultural. Contudo, crianças e adolescentes não foram significados sempre da mesma forma pela sociedade. Nesse sentido, retomando os registros do historiador francês Philippe Ariès (1978), fica evidente que a concepção de infância como uma etapa distinta da vida é bastante recente e esteve associada ao surgimento da família no modelo nuclear, do estado nação e da nova forma de organização do trabalho, entre o século XVIII e início do século XIX. Antes do século XVI, de acordo com Ariès (1978) crianças e adolescentes eram tratados como adultos, recebendo as mesmas responsabilidades e assumindo o mesmo papel social. A noção de infância, portanto, começa a se desenhar somente no século XVII e o interesse pela adolescência emerge a partir de 1890 em temas literários, bem como na preocupação de políticos e de responsáveis pela manutenção da ordem.

Um exemplo contemporâneo, especificamente na sociedade brasileira, que confirma essa construção social da noção de infância é a disparidade que há entre a concepção de criança encontrada no extinto Código de Menores, em vigor a partir de 1927 (BRASIL, 1926), e o atual Estatuto da Criança e do Adolescente, de 1990 (BRASIL, 1990), haja vista que o primeiro foi 
elaborado para tratar somente do caso dos menores abandonados e dos considerados delinquentes enquanto que o segundo apresenta a tônica da prevenção, da proteção da infância e trata das crianças e adolescentes como sujeitos de direito. O citado Código caracterizou-se como a primeira intervenção estatal para este público. Todavia, cabe destacar que ambos têm a finalidade premente de manutenção da ordem social. Conforme Hadler (2010, p. 309), o citado Estatuto promove uma normatização da infância, instituindo "uma essência fixa e imutável a ser seguida" e, com isso, produz "rotulações sobre a alteridade".

Salles (2005) examina a infância e a adolescência na sociedade contemporânea e destaca que o surgimento da concepção de infância e adolescência se comunica diretamente com os interesses da sociedade industrial, perpassando as leis trabalhistas e o sistema educacional. Em seu artigo, a autora conclui afirmando que embora a criança seja reconhecida como sujeito de direitos na sociedade atual, as práticas excludentes ainda vigoram nas esferas sociais e políticas contra crianças, adolescentes e jovens.

A autora considera ativamente a influência social, histórica e cultural neste processo, e deste modo, evidencia-se que a sociedade moderna busca de alguma forma a segurança de sistematizar certa previsibilidade ao sujeito, o que se expressa nas próprias normativas legais que buscam definir quem é a criança e o adolescente e o que se deve ou não esperar dele. As políticas sociais e educacionais, como bem aponta Salles (2005) exprimem esta tarefa de socialização e amoldamento à cultura.

Guareschi (2007) esclarece que a era tecnológica com suas novas formas de subjetivação instaura o paradoxo da busca por "multiplicação e provisoriedade das formas de subjetividades" e por "marcadores identitários que tornariam essas subjetividades essencializadas e permanentes como a infância e a adolescência" (p. 255). A autora defende a busca pela desnaturalização dos fenômenos classificados como próprios da infância e da adolescência, especialmente pela psicologia, de modo que as relações entre poder e verdade possam ser questionadas.

Para Guareschi (2007), a psicologia tem estado a serviço das formas de governo por meio do esquadrinhamento e classificação de condutas e afirma que esta alcança seu status na objetivação do indivíduo, tornando-o responsabilizável e conformando, com isso, uma estratégia de controle das populações.

A psicologia do desenvolvimento, por exemplo, inicia seus estudos em 1900 e, embora sob diferentes análises teóricas, observa-se um ponto em comum nas teorizações: o desenvolvimento para a maturidade. Conforme Pan e Faraco (2005), a psicologia do Barbarói, Santa Cruz do Sul, n. 58, p.<65-94>, jan./jun. 2021 
desenvolvimento busca o aperfeiçoamento do ser humano até a idade da razão, cumprindo a tarefa de desenvolver o projeto iluminista, o qual objetiva a utilidade, a produtividade e o lucro.

Instaura-se uma fronteira entre público e privado endossada pelas práticas psicológicas, a qual localiza a pobreza, a população e o Estado na primeira categoria e o eu interior na segunda (GUARESCHI, 2007).

As tecnologias do bem-estar social ganham acesso ao cotidiano das comunidades a fim de garantir que a manifestação do eu interior siga um modelo de equilíbrio social, tornando o privado uma condição para salvaguardar o público. Nesse sentido, a concepção de infância e adolescência na sociedade atual torna-se uma forma de poder que permite a disciplinarização de corpos com o objetivo de bem integrá-los à ordem social. Os saberes científicos e jurídicos, por sua vez, apresentam como parâmetros estes critérios objetivistas e naturalistas a fim de traçar certa previsibilidade e controle sobre o que é esperado do indivíduo em cada uma das etapas da vida. Logo, o Estado é chamado a intervir na equiparação da infância dita de risco à infância considerada normal a partir dos valores propagados pelo liberalismo (GUARESCHI, 2007).

Guareschi (2007) frisa, ainda, que as possibilidades de dominação na atualidade não dependem mais da existência de um espaço físico concreto, pois o mundo está configurado em uma rede e os relacionamentos estão virtualizados, emergindo novas formas de subjetividade e de governo da vida.

Sobre a temática da subjetividade, Pan (2003) expõe a artificialidade do conceito de subjetividade na sociedade atual, que passa pela noção de produção e consumo, rompendo com a clássica definição de subjetividade como identidade, ou seja, algo estável, individual e singular. Com Foucault, Pêcheux e Bakhtin convoca-se a necessidade de "romper com qualquer filosofia da consciência ou com qualquer teoria psicológica que confere a um núcleo pessoal e individual a atribuição de significados ao mundo" (PAN, 2003, p. 106).

Pan e Faraco (2005) analisam que o conhecimento da infância, como objeto de investigação científica e conformado às ciências naturais, é um projeto iluminista, o qual pode ser compreendido como "uma tradição cultural que se define pela postura crítica (...). Tem por objetivo libertar o ser humano para o desempenho, e, com seu poder técnico e manipulatório sobre a natureza, domá-la e submetê-la às suas próprias finalidades" (PAN; FARACO, 2005, p. 372).

Esse modelo de ciência acaba por desumanizar o indivíduo "da mesma forma que os sistemas políticos e ideológicos o fazem" (PAN; FARACO, 2005, p. 372), apagando as Barbarói, Santa Cruz do Sul, n. 58, p.<65-94>, jan./jun. 2021 
diferenças e subestimando a experiência cotidiana, por fim, trata o homem como um objeto mudo (PAN; FARACO, 2005).

Conforme Pan e Faraco (2005), a subjetividade neste modelo é situada fora das relações e as desigualdades humanas são naturalizadas e dissociadas dos processos subjetivos.

Castro (2002) argumenta na mesma direção: a infância é uma construção de cada grupo social e não uma essência em si mesma. E toda definição de infância nasce em meio a conflitos de interesse da sociedade, pois adultos e crianças são considerados diferentes em qualquer cultura humana, e esta diferença é produzida social e historicamente. Monteiro e Castro (2008, p. 274) explicam que "a razão desenvolvimentista é embasada pela crença na primazia da razão, fortemente enraizada no modo de ser ocidental a partir dos pressupostos cartesianos". Este pensamento, que se exemplifica nos estudos piagetianos, conquistou grande influência sobre as práticas educacionais e sobre a normalização do processo de desenvolvimento infantil. Monteiro e Castro (2008, p. 280) afirmam que "a lógica desenvolvimentista favoreceu uma perspectiva de 'menoridade' sobre a infância, que põe em questão, ou mesmo reduz seus direitos civis e políticos".

Segundo Castro (2002), para a infância moderna, há um discurso determinista, que se pretende universal, fundamentado no colonialismo e no padrão do homem branco europeu, o qual coloca de um lado a figura da fragilidade, da inocência da infância, e de outro a do adulto, racional e autônomo, figura essa que transita do primeiro estado para o segundo por meio de um processo de desenvolvimento, transformando-se com o objetivo de dominar a si e a natureza. A relação da criança com o mundo do trabalho já é forjada desde o início por meio da escola. A educação é um direito, que conforme explicitam Monteiro e Castro (2008), assume caráter de dever, pois não existe somente para benefício do indivíduo uma vez que o bom funcionamento da sociedade depende de indivíduos educados. A autora aponta também que embora as crianças sejam apartadas das decisões do mundo adulto, das políticas públicas e da repartição das riquezas sociais, tanto elas como os adultos estão implicados na construção do mundo em que vivemos. A cidadania, conforme demonstram Monteiro e Castro (2008, p. 277) figura como um mecanismo de controle do Estado, o qual assegura "direitos sociais, que aparecem, então, como forma de controle e assistência por parte do Estado, em troca de aquisições protetivas". Na nova lógica do capitalismo a criança situa-se como mais um consumidor, além de um potencial trabalhador e, na atualidade, Castro (2002) defende que a criança aparece ainda como quem também ocupa e conquista o cenário social. 
Sobre a formulação de políticas públicas, estas autoras (2008) analisam que a representação social de crianças e jovens na década de 70 era de objeto, seja de assistência (proteção social), controle ou repressão social. A partir dos anos 80 e 90 crianças e jovens aparecem na formulação de leis e políticas públicas como sujeito de direitos e as práticas passam a buscar a defesa destes indivíduos em função da condição peculiar de pessoas em desenvolvimento - condição esta amparada pela própria Constituição Federal de 1988. O estabelecimento da Convenção Internacional dos Direitos da Criança (1989), embora desconsiderasse as peculiaridades de cada cultura, defendeu que a criança fosse tratada como sujeito, ator e cidadão. Um dos efeitos desta concepção foi a criação do Estatuto da Criança e do Adolescente.

É preciso, portanto, problematizar essa noção de infância e adolescência legitimada na sociedade contemporânea a fim de melhor compreender os sentidos da juventude e seus efeitos a partir das políticas de Estado, pois estas atuam na classificação de condutas e no controle social a fim de equiparar o que se chama infância de risco com infância normal em nome dos valores do liberalismo, que naturalizam as desigualdades humanas e as dissociam dos processos subjetivos com vistas à preparação para inserção produtiva.

Diante disso, falar sobre o jovem na contemporaneidade é também considerar a atual era tecnológica e analisar mais detidamente as possibilidades que tais inovações apresentam para a constituição de sistemas de governança da sociedade e dos indivíduos.

\section{IDENTIDADE E GOVERNO NA POLÍTICA DE APRENDIZAGEM PROFISSIONAL: O QUE É "SER APRENDIZ", AFINAL?}

A política de aprendizagem profissional, portanto, se apresenta como uma estratégia do Estado para a solução do jovem de risco, pois conforme Hüning e Guareschi (2002), a classificação de pessoas como a de risco, demarca uma diferença e requer instituições e programas para atendimento destas demandas de modo que se instauram práticas de governabilidade que naturalizam a condição objetivada de crianças e adolescentes em situação de risco social.

Muito embora a política de aprendizagem profissional não descreva seu público-alvo como sendo aquele das camadas populares, evidencia-se que a prioridade do Estado está em atender a infância "marginal” e "de risco", conforme apontam Hüning e Guareschi (2002, p. 44), pois este último termo, "de risco", tem sido alvo de ações governamentais nas esferas da assistência social e da educação. Logo de início, portanto, o jovem que se encaixa nesta 
definição é posto à margem da sociedade e deverá observar determinadas prescrições se quiser um dia integrá-la. Deste modo, deposita-se a culpa no outro e no meio familiar e não na sociedade, pois se o indivíduo estivesse integrado, talvez não fosse de risco. Surgem então os mitos que engendram discursos de verdade e estabelecem alvos para correção e adequação, como acontece, por exemplo, com adolescentes considerados de risco e pertencentes às classes categorizadas como perigosas. Esta linguagem, por sua vez, imbricada nos programas sociais que se voltam para tal população produz efeitos para além destas instâncias, fundamentando uma separação entre quem governa e quem é governado, em uma busca por normatização.

É imperioso considerar que a identidade surge, conforme Hüning e Guareschi (2002), no interior das relações de poder como um produto da diferença com relação ao outro, com o que não se é. As identidades, então, compõem sistemas de significação que demarcam grupos sociais em uma desestabilização contínua advinda das diferenças que convocam a todo o momento novas posições identitárias, sustentadas pela exclusão. A diferença, portanto, sustenta-se na cultura, com seus sistemas classificatórios, implicados com relações de poder, o poder de demarcar a normalidade. Com isso, os tutelados são compreendidos como aqueles que carecem do padrão instituído como normalidade e precisam ser auxiliados com vistas à adequação.

Importa analisar que desde o fim do século XIX, a preocupação social com pessoas em situação de risco surge não apenas para solucionar a problemática enfrentada pela própria pessoa, mas também resolver a ameaça que tal situação expõe à ordem social, como bem demonstram Hüning e Guareschi (2002). Neste cenário, o adolescente passa a ser protegido da sociedade que também se protege dele, "em um processo de correção de identidades desviantes ou identidades de risco" (HÜNING; GUARESCHI, 2002, p. 49).

As citadas autoras (2002) chamam a atenção para o fato de que futuros passam a ser preditos na linguagem da noção de risco social, do Estatuto da Criança e do Adolescente, de cujos sujeitos já são muitas vezes culpabilizados pelo que podem se tornar, engendrando ações de controle que antecipam medidas preventivas que focam a irregularidade no indivíduo. Mesmo após a ditatura militar o foco ainda se trata do uso de tecnologias de governabilidade para manutenção da ordem social e modelagem de identidades e da relação do indivíduo consigo mesmo, incluindo a responsabilidade de auto gerenciar o seu risco.

Nesse sentido, com a política de aprendizagem profissional, o Estado atua como aquele que oferta ao jovem de risco uma oportunidade de entrada no mercado de trabalho, isto é, ser aprendiz é a oportunidade de aprendizagem e inclusão, é uma identidade construída, uma forma 
de gestão da identidade do jovem que impõe a responsabilidade de ele gerenciar o próprio risco, contudo, a simples entrada não oferece garantias de permanência e isto não é previsto na política.

Logo, de acordo com o argumento de Rose (1998), a tarefa central da organização moderna é a "administração da subjetividade" (p. 32) e as formas de pensar e agir disseminadas pelas autoridades que assumem a frente deste "governo da alma" afetam as formas de ser e de interagir da sociedade em geral. O citado autor justifica o uso da palavra "governo" por designar ações diretas, por meio da persuasão e não da violência direta, sobre os indivíduos a fim de conquistar fins sociais e políticos, ações estas que instauram novos regimes de verdade que resultam em um poder que gera exclusão.

\section{CONCLUSÃO}

A juventude tem encontrado denominações como o dito normal, marginal e de risco. Este último termo, de risco, tem sido alvo de ações governamentais nas esferas da assistência social e da educação. Na leitura realizada, o intertexto das políticas estudadas permite concluir que o sentido negativo "de risco" é transfigurado para "aprendiz".

As políticas públicas, especialmente a de assistência social e a de aprendizagem profissional, visam solucionar problemas políticos, não estando livres, portanto, de um posicionamento ético-político, pois se situam nas relações de poder entre o Estado e a sociedade, reproduzindo como efeito os sentidos que elas anunciam.

A política de aprendizagem profissional não erradicou o trabalho infantil, mas sim o regulou, estabelecendo em conformidade com as teorias contemporâneas sobre o desenvolvimento infantil e com os objetivos governamentais o modelo de trabalho que se considera adequado aos jovens. A contradição desta proposta de trabalho protegido reside no fato de que ela parece apoiar-se no mesmo princípio que rege o trabalho infantil: a ideia de que é melhor trabalhar do que ficar na ociosidade. Deste modo, à infância de risco ou marginal é atribuída uma solução por meio dos sentidos construídos socialmente para o trabalho, como por exemplo, o de dignificação, tornando assim produtivos - de uma maneira pré-formatada aqueles de quem a sociedade quer se proteger por serem considerados perigosos, ou seja, de risco social.

Como a subjetividade sofre a influência dos referenciais linguísticos é impactada por esta noção socialmente construída sobre o trabalho e sobre a concepção de infância normal versus de risco que demanda disciplinarização. 
Esta disciplinarização da infância e da adolescência para a socialização e posterior inserção adaptada no mundo do trabalho é um papel premente das políticas públicas apoiado em estudos médicos, psicológicos e pedagógicos com o objetivo de normatizar e explicar os comportamentos observados nestas diferentes fases da vida.

Com isso, a política pública pode, em princípio, defender a garantia dos direitos sociais, mas em última instância, reafirmar as desigualdades socioculturais por meio da gestão das identidades.

Historicamente, a assistência à juventude no Brasil tem a marca do olhar sobre a deficiência e os problemas, bem como da busca pela normalização, da regulamentação e, nesse sentido, as políticas públicas incorporam o sentido do risco, do diferente que demanda normalização, por meio do uso de estratégias de intervenção, prevenção e controle. Desde o Código de Menores, o termo menor ajudou a dar forma à noção de periculosidade, a qual foi se consolidando desde então e constituindo um marcador identitário.

A identidade surge no interior das relações de poder como um produto da diferença com relação ao outro, com o que não se é. As identidades, então, compõem sistemas de significação que demarcam grupos sociais em uma desestabilização contínua advinda das diferenças que convocam a todo o momento novas posições identitárias, sustentadas pela exclusão. A diferença, portanto, sustenta-se na cultura, com seus sistemas classificatórios, implicados com relações de poder, o poder de demarcar a normalidade. Com isso, os tutelados são compreendidos como aqueles que carecem do padrão instituído como normalidade e precisam ser auxiliados com vistas à adequação.

Em conclusão, observa-se que há uma construção de um sentido sobre o sujeito de risco que o generaliza e nos fornece um mapeamento sobre ele, não nos permitindo ou incentivando a aproximação e o conhecimento do outro. Trata-se do outro como se já o conhecêssemos e pudéssemos prevê-lo, antecipando até mesmo as ações que adotaremos para ajudá-lo. Ajudá-lo em demandas que nós identificamos, sem a participação e sequer a anuência deste outro. Pensase por eles e não com eles. É como se houvesse uma possibilidade única de identidade: a identidade de risco.

As novas tecnologias de governo, portanto, tentam monologizar o discurso sobre a subjetividade do jovem de risco, fortalecendo os processos de exclusão social. Evidencia-se, com isso, que a lei, mesmo existente, protege os jovens marginalizados, mas de um certo modo, marcando seu lugar - o lugar da identidade de risco. Isso significa uma proteção às avessas: o Estado se protege - oferecendo oportunidade de aprendizagem no mercado - e protege a 
sociedade, garantindo pela fixação da identidade do aprendiz - o jovem de risco - o controle da alteridade.

Diante do exposto, quando as desigualdades humanas são naturalizadas e os processos subjetivos fabricados a partir de uma concepção de juventude de risco, pessoal e, principalmente, social, os efeitos de classificação e estigmatização difundidos nos discursos circulantes nas políticas públicas - que são dirigidas a determinadas classes sociais - constituem para a sociedade um parâmetro que dita o que é certo, o que é verdadeiro.

Por fim, aponta-se para a necessidade de problematizar os sentidos da proteção social para o jovem e para a sociedade, bem como os seus efeitos, especialmente na política de aprendizagem profissional, a qual não afeta somente seus destinatários, mas a toda a sociedade, uma vez que regula formas de viver, fabrica modelos identitários e gesta a existência de cada indivíduo objetivando sua conformação. Esta função intrínseca das políticas públicas demanda um olhar constante e reflexivo que instigue o debate sobre a visão de homem e de mundo que se está difundindo a fim de avaliar quais serão os efeitos de sentido destas práticas. As políticas públicas, portanto, não podem assumir um caráter normativo, inquestionável, pois a esfera social é complexa e requer uma revisão constante.

\title{
TO BE AN APPRENTICE: MEANINGS OF YOUTH ON THE PUBLIC POLICY OF PROFESSIONAL APPRENTICESHIP
}

\begin{abstract}
This article analyses the meanings attributed to the young person as seen by Brazilian public policy of professional apprenticeship and how the government technologies of the individual work on the production of the concept social risk. It is a documental study based on Mikhail Bakhtin's reading theory, in which utterances are analysed aiming at their denaturalisation. A set of norms regarding this policy has been selected, read and analysed as texts and intertexts, producing a complex dialogic web and casting light on the positioning of the state government concerning the meaning of apprentice and social protection, therefore directed to the target audience of this social care policy. The meaning of the identity of the youth seen as at risk is the main target of this policy, which regulates work before the age of 18 , identifying the young person as an apprentice. This study evinces the characteristics of this process as normative and regulatory, although the social sphere is complex, requiring constant revision. Considering the naturalisation of the meaning of youth, the public policies for the young person are presented as contradictory and distant from the specific needs of this population. This study shows the necessity to problematize the meanings of social care for youth and for society, and its effects, particularly regarding the policy for professional apprenticeship, which affects not only its receiver, but also the whole society, since it acts on the fabrication of an identity model and manages the existence of the individuals, aiming at their conformity.
\end{abstract}

Keywords: YouthIdentity; apprentice; public policy of professional apprenticeship; social risk 


\title{
SER APRENDIZ: LOS SENTIDOS DE LA JUVENTUD EN LA POLÍTICA PÚBLICA DE APRENDIZAJE PROFESIONAL
}

\begin{abstract}
Resumen
Este articulo analiza los sentidos atribuidos al joven configurado por la actual política pública brasilera de aprendizaje profesional y cómo operan las tecnologias de gobierno del individuo en la producción de la noción de riesgo social. Es un estudio documental basado en la teoría de lectura Bajtiniana, que analiza los enunciados buscando su desnaturalización. Un conjunto de normativas referidas a esa política fueron analizados como textos e intertextos que producen una red dialógica compleja que evidencia el posicionamiento del Estado en relación al significado de ser aprendiz, el cual involucra la noción de protección social, por lo tanto direccionado al público objeto de la política de asistencia social. El sentido de la identidad del joven considerado en riesgo es el principal objetivo de la política, que reglamenta el trabajo antes de los 18 años identificándolo como aprendiz. El estudio evidencia el caracter normativo y regulador de ese proceso aunque la esfera social sea compleja y requiera una revisión constante. Delante de la naturalización del concepto de juventud constatado, las políticas públicas volcadas hacia el joven se presentan contradictorias y distantes de las demandas específicas de ésta población. Este estudio apunta la necesidad de problematizar los sentidos de la protección social para el joven y la sociedad, también como sus efectos, especialmente en la política de aprendizaje profesional, la cual no afecta solamente su destinatario, sino a toda la sociedad, una vez que actua en la fabricación de un modelo identitario y gesta la existencia de los indivíduos buscando su conformación.
\end{abstract}

Palabras-clave: identidad; aprendiz; política pública de aprendizaje profesional; riesgo social.

\section{REFERENCIAS}

ALVES, L. A. Referenciais para Formação de Professores: uma análise crítica sobre o discurso da qualidade e competência, do ponto de vista da psicologia escolar. In: VIÉGAS, L de S.; ANGELUCCI, C. B. (Orgs.) Políticas Públicas em Educação: uma análise crítica a partir da psicologia escolar. São Paulo: Casa do Psicólogo, 2011.

ARIÈS, P. História Social da Criança e da Família. Ed. LTC: 1978.

BAKHTIN, M. O Discurso no Romance. Questões de Literatura e Estética: A Teoria do Romance. São Paulo: HUCITEC, 1988.

BRASIL. Constituição da República Federativa do Brasil de 1988. Diário Oficial [da República Federativa do Brasil], Brasília, DF, n. 191-A, 05 out. 1988. Seção I, p. 1-32.

BRASIL. Decreto n ${ }^{\circ} 5.083$, de $1^{\circ}$ de dezembro de 1926. Institui o Código de Menores. Diário Oficial [da República Federativa do Brasil], Brasília, DF, n. 276, 04 dez. 1926. Seção I, p. 22124.

BRASIL. Decreto ${ }^{\circ} 5.598$, de $1^{\circ}$ de dezembro de 2005. Regulamenta a contratação de aprendizes e dá outras providências. Diário Oficial [da República Federativa do Brasil], Brasília, DF, n. 231, 02 dez. 2005. Seção I, p. 2-4.

BRASIL. Lei n 8.069, de 13 de julho de 1990. Dispõe sobre o Estatuto da Criança e do Adolescente e dá outras providências. Diário Oficial [da República Federativa do Brasil], Brasília, DF, n. 135, 16 jul. 1990. Seção I, p. 13563-13577. 
BRASIL. Lei $\mathrm{n}^{\circ}$ 10.097, de 19 de dezembro de 2000. Altera dispositivos da Consolidação das Leis do Trabalho - CLT. Diário Oficial [da República Federativa do Brasil], Brasília, DF, n. 244-E, 20 dez. 2000a. Seção I, p. 1-2.

BRASIL. Lei ${ }^{\circ} 12.435$, de 6 de julho de 2011. Altera a Lei $n^{\circ} 8.742$, de 7 de dezembro de 1993, que dispõe sobre a organização da Assistência Social. Diário Oficial [da República Federativa do Brasil], Brasília, DF, n. 129, 07 jul. 2011a. Seção I, p. 1-3.

BRASIL. Lei no 12.868, de 15 de outubro de 2013. Altera a Lei no 12.793, de 2 de abril de 2013, para dispor sobre o financiamento de bens de consumo duráveis a beneficiários do Programa Minha Casa, Minha Vida (PMCMV); constitui fonte adicional de recursos para a Caixa Econômica Federal; altera a Lei no 12.741, de 8 de dezembro de 2012, que dispõe sobre as medidas de esclarecimento ao consumidor, para prever prazo de aplicação das sanções previstas na Lei no 8.078, de 11 de setembro de 1990; altera as Leis no 12.761, de 27 de dezembro de 2012, no 12.101, de 27 de novembro de 2009, no 9.532, de 10 de dezembro de 1997, e no 9.615, de 24 de março de 1998; e dá outras providências. Diário Oficial [da República Federativa do Brasil], Brasília, DF, n. 201, 16 out. 2013a. Seção I, p. 1-4.

BRASIL. Manual da Aprendizagem: o que é preciso saber para contratar o aprendiz. Brasília: MTE, 2011c.

BRASIL. Ministério do Desenvolvimento Social e Combate à Fome. Secretaria Nacional de Assistência Social. Orientações Técnicas - Programa Nacional de Promoção de Acesso ao Mundo do Trabalho - ACESSUAS TRABALHO. Brasília: MDS, $2013 \mathrm{~b}$.

BRASIL. Ministério do Desenvolvimento Social e Combate à Fome. Política Nacional de Assistência Social - PNAS. Brasília: MDS, 2004.

BRASIL. Projeto de Lei ${ }^{\circ} 2.845$, de 26 de abril de 2000. Altera dispositivos da Consolidação das Leis do Trabalho, aprovada pelo Decreto-Lei n2 5.452, de 12 de maio de 1943. Diário da Câmara dos Deputados, Brasília, DF, n. 74, 26 abr. 2000b. p. 18686.

BRASIL. Resolução n ${ }^{\text {3 33, de }} 28$ de novembro de 2011. Define a Promoção da Integração ao Mercado de Trabalho no campo da assistência social e estabelece seus requisitos. Diário Oficial [da República Federativa do Brasil], Brasília, DF, n. 228, 29 nov. 2011b. Seção I, p. 114-115.

CASTRO, L. R. A Infância e seus Destinos no Contemporâneo. Psicologia em Revista, [Online] v. 8, n. 11, p. 47-58. Jun. 2002. Disponibilidade:

<http://www.pucminas.br/imagedb/documento/DOC_DSC_NOME_ARQUI20041214154058 .pdf $>$. Data de acesso: 06 jun.2015.

CRUZ NETO, O.; MOREIRA, M. R. Trabalho infanto-juvenil: motivações, aspectos legais e repercussão social. Cad. Saúde Pública, [Online] Rio de Janeiro, v. 14, n. 2, p. 437 -

441, abr. 1998. Disponibilidade:

<http://www.scielo.br/scielo.php?script=sci_arttext\&pid=S0102-

311X1998000200029\&lng=pt\&nrm=iso>. Data de acesso: 04 out. 2015.

CURITIBA. Adolescente Aprendiz - Capacitação, [Online] Disponibilidade:

Barbarói, Santa Cruz do Sul, n. 58, p.<65-94>,jan./jun. 2021 
<http://www.curitiba.pr.gov.br/servicos/cidadao/adolescente-aprendiz-capacitacao/356>. Data de acesso: 04 set. 2013.

DIMENSTEIN, M. Introdução - Psicologia, Política e Produção em Saúde. In: GUARESCHI, N. M. F. (org.). Psicologia, Formação, Política e Produção em Saúde. Porto Alegre: EDIPUCRS, 2010.

FLICK, U. Utilização de Documentos como Dados. Introdução à Pesquisa Qualitativa. 3. ed. Porto Alegre: Artmed, 2009.

FOUCAULT, M. A Hermenêutica do Sujeito. 1981 - 1982. 3. ed. São Paulo: Martins Fontes, 2010.

GUARESCHI, N. Infância, Adolescência e a Família: práticas psi, sociedade contemporânea e produção de subjetividade. In: Jacó-Vilela, A.; Sato, L.; Matos, A. Diálogos em Psicologia Social. Porto Alegre: ABRAPSO Sul, 2007.

HADLER, O. H. Políticas Públicas, Formas de Governo e Práticas Institucionais: nas trilhas de João e Maria. In: GUARESCHI, N. M. F. (org.). Psicologia, Formação, Política e Produção em Saúde. Porto Alegre: EDIPUCRS, 2010.

HÜNING, S. M.; GUARESCHI, N. M. de F. Tecnologias de Governo: constituindo a situação de risco social de crianças e adolescentes. Revista Currículo sem Fronteiras, v. 2, n. 2, p. 4156, jul. / dez. 2002.

KASSOUF, A. L. O que conhecemos sobre o trabalho infantil?. Nova econ., [Online] Belo Horizonte, v. 17, n. 2, p. 323-350, aug. 2007. Disponibilidade: $<$ http://www.scielo.br/scielo.php?script=sci_arttext\&pid=S010363512007000200005\&lng=en\&nrm=iso>. Data de acesso: 04 out. 2015.

MACHADO, J. P.; PAN, M. A. G. de S. Assistência Estudantil: sentidos em (trans)formação. In: FERRARINI, N. da L.; RUPPEL D. Inclusão Racial e Social: considerações sobre a trajetória UFPR. Curitiba: Editora UFPR, 2013.

MACHADO, J. P.; PAN, M. A. G. de S. Do Nada ao Tudo: políticas públicas e a educação especial brasileira. Revista Educação e Realidade, [Online] Porto Alegre, v. 37, n. 1, p. 273294, jan. / abr. 2012. Disponibilidade: 〈http://www.ufrgs.br/edu_realidade〉. Data de acesso: 10 out. 2014.

MACHADO, J. P.; PAN, M. A. G. de S. Política Pública e Subjetividade: a assistência estudantil na universidade. Revista Textos \& Contextos. Porto Alegre, v.13, n. 1, p. 184-198, jan. / jun. 2014.

MONTEIRO, R. A. de P.; CASTRO, L. R. de A Concepção de Cidadania como Conjunto de Direitos e sua Implicação para a Cidadania de Crianças e Jovens. Associação Brasileira de Psicologia Política, [Online] v. 8, n. 16, p.271-284. jul. / dez. 2008. Disponibilidade:

<http://pepsic.bvsalud.org/scielo.php?pid=S1519-549X2008000200006\&script=sci_arttext>. Data de acesso: 06 jun. 2015.

PAN, M. A. G. de S. Infância, Discurso e Subjetividade: uma discussão interdisciplinar para Barbarói, Santa Cruz do Sul, n. 58, p.<65-94>, jan./jun. 2021 
uma nova compreensão dos problemas escolares. Curitiba, 2003. Tese (Doutorado em Linguística) - Setor de Ciências Humanas, Letras e Artes. Universidade Federal do Paraná.

PAN, M. A. G. de S.; FARACO, C. A. Os sentidos da infância: um estudo sobre processos subjetivos na instituição escolar. Interação em Psicologia (Qualis/CAPES: A2), [Online] [S.1.], abr. 2005. ISSN 1981-8076. Disponibilidade:

<http://ojs.c3sl.ufpr.br/ojs2/index.php/psicologia/article/view/4779>. Data de acesso: 06 out. 2015.

ROSE, N. Governando a Alma: a Formação do Eu Privado. In: SILVA, T. T. da (org.). Liberdades Reguladas. Petrópolis: Vozes, 1998.

RUA, M. das G. As Políticas Públicas e a Juventude dos Anos 90. Brasília: CNPD,1998.

SALES, P. E. N.; OLIVEIRA, M. A. M. Educação Profissional e Aprendizagem no Brasil: trajetórias, impasses e perspectivas. II SENEPT - SEMINÁRIO NACIONAL DE EDUCAÇÃO PROFISSIONAL E TECNOLÓGICA, 2010, Minas Gerais. Anais II SENEPT 2010, Belo Horizonte: CEFET-MG, 2010, p.1-18.

SALLES, L. M. F. Infância e Adolescência na Sociedade Contemporânea: alguns apontamentos. Revista Estudos de Psicologia., [Online] Campinas, jan. / mar. 2005. Disponibilidade: <http://www.scielo.br/scielo.php?script=sci_arttext\&pid=S0103166X2005000100005>. Data de acesso: 10 jan. 2015.

SCISLESKI, A.; GUARESCHI, N. M. de F. Governando a Vida: (pro)vocações para a psicologia. In: GUARESCHI, N. M. F. (org.). Psicologia, Formação, Política e Produção em Saúde. Porto Alegre: EDIPUCRS, 2010.

SILVA, J. V. da; CORGOZINHO, J. P. Atuação do psicólogo, SUAS/CRAS e Psicologia Social Comunitária: possíveis articulações. Psicol. Soc., [Online] Florianópolis, v. 23, n. spe, p. 12-21, 2011. Disponibilidade:

<http://www.scielo.br/scielo.php?script=sci_arttext\&pid=S0102-

$71822011000400003 \& \operatorname{lng}=$ pt\&nrm=iso $>$. Data de acesso: 05 out. 2015.

SOUZA, D. J. R. de Sobre uma Psicologia Oficial e seus Efeitos de Sentido: uma análise das normativas do Conselho Federal de Psicologia. 2014. 164 f. Dissertação (Mestrado em Psicologia) - Universidade Federal do Paraná, Curitiba, 2014. 1 CD-ROM.

SPINK, M. J. P.; BRIGAGÃO, J. I. M.; NASCIMENTO, V. L. V. do; CORDEIRO, M. P. A Produção de Informação na Pesquisa Social: compartilhando ferramentas. Rio de Janeiro, Centro Edelstein de Pesquisas Sociais, 2014.

SPOSITO, M. P. Trajetórias na constituição de políticas públicas de juventude no Brasil. In. FREITAS, M.V; PAPA, F.C. Políticas públicas: juventude em pauta. 2.ed. São Paulo: Cortez: Ação Educativa Acessória, Pesquisa e Informação: Fundação Friedrich Ebert, 2008.

XIMENES, V. M.; PAULA, L. R. C. de; BARROS, J. P. P. Psicologia comunitária e política de assistência social: diálogos sobre atuações em comunidades. Psicol. cienc. prof.,

[Online] Brasília, v. 29, n. 4, p. 686-699, 2009. Disponibilidade:

$<$ http://www.scielo.br/scielo.php?script=sci_arttext\&pid=S1414-

Barbarói, Santa Cruz do Sul, n. 58, p.<65-94>,jan./jun. 2021 
98932009000400004\&lng=en\&nrm=iso>. Data de acesso: 05 out. 2015.

ZANELLA, A. V.; GROFF, A. R.; SILVA, D. O. B. da; MATTOS, L. K. de; FURTADO, J. R.; ASSIS, N de. Jovens, Juventude e Políticas Públicas: produção acadêmica em periódicos Científicos brasileiros. Estudos de Psicologia. v. 18, n. 2, p.1-11. Natal, abr. / jun. 2013.

Data de recebimento: $27 / 02 / 2016$

Data de aceite: $13 / 10 / 2020$

\section{Sobre as autoras:}

Thaís Ellen Gomes Provenzi é Mestre em Psicologia pela Universidade Federal do Paraná, Especialista em Direito Público pela UNIASSELVI com MBA em Gestão de Pessoas pela SPEI e Graduada em Psicologia pela Universidade Federal do Paraná. Atuou como Psicóloga na Prefeitura Municipal de Curitiba, como docente no Centro Universitário Campos de Andrade no curso de Psicologia e como Professora Assistente na Universidade Federal do Paraná no curso de pós-graduação em Gestão em Saúde. Endereço Eletrônico: prof.thaisprovenzi@gmail.com

Miriam Aparecida Graciano de Souza Pan é Doutora em Letras pela Universidade Federal do Paraná, com Pós-Doutorado na University of Texas at Austin. Formada em Psicologia e Fonoaudiologia, atua como professora dos Programas de Pós-graduação em Psicologia e em Educação da Universidade Federal do Paraná. Endereço Eletrônico: miriamagspan@yahoo.com.br 